\title{
SYSTEMS APPROACHES TO HEALTHCARE SYSTEMS DESIGN AND CARE DELIVERY: AN OVERVIEW OF THE LITERATURE
}

\author{
Komashie, Alexander (1,2); \\ Hinrichs-Krapels, Saba (3); \\ Clarkson, P. John (1) \\ 1: Department of Engineering, University of Cambridge, Cambridge, UK; \\ 2: THIS Institute (The Healthcare Improvement Studies Institute), University of Cambridge, \\ Cambridge, UK; \\ 3: Department of Multi-Actor Systems, Delft University of Technology, Delft, Ne
}

\begin{abstract}
The healthcare sector is facing significant challenges that require a systems approach, resulting in a rapid growth in the application of systems approaches in healthcare since the beginning of the $21 \mathrm{st}$ century. Consequently, healthcare practitioners and policymakers now desire to understand the evidence-base for the approach, but little evidence of the kind desired exists. This paper is a first step in conducting a narrative review of the application of systems approaches in healthcare based on a systematic review of the academic and grey literature. First, the emergence of the approach in healthcare is explored. Second, specific examples of applications of systems approaches in healthcare are examined to identify any missing elements in current practice. Third, fourteen reviews of the approach in healthcare published in the last ten years are analysed. The results suggest that the use of the approach in healthcare will most likely continue to increase, however, significant work remains for the design and systems community to demonstrate the effectiveness of systems approaches, specifically in providing convincing measures of impact on patient and service outcomes.
\end{abstract}

Keywords: Systems Engineering (SE), Design engineering, Service design, Healthcare design, healthcare quality improvement

\section{Contact:}

Komashie, Alexander

University of Cambridge

Engineering

United Kingdom

A.Komashie@eng.cam.ac.uk

Cite this article: Komashie, A., Hinrichs-Krapels, S., Clarkson, P. J. (2021) 'Systems Approaches to Healthcare Systems Design and Care Delivery: An Overview of the Literature', in Proceedings of the International Conference on Engineering Design (ICED21), Gothenburg, Sweden, 16-20 August 2021. DOI:10.1017/pds.2021.555 


\section{INTRODUCTION}

In 1917, Pool and Bancroft reported on the growing complexity of the healthcare delivery systems of the time (Pool and Bancroft, 1917). They argued that a systems approach had 'become essential' in managing that complexity. In their view, that complexity was manifested in the size of services, complicated methods of diagnosis, larger staff numbers and rapid turnover (Pool and Bancroft, 1917). One hundred years later, it is reasonable to say that modern-day care delivery systems are several magnitudes more complex than they observed in 1917, yet a systems and design approach to healthcare improvement is neither fully appreciated nor common place in healthcare (President's Council of Advisors on Science and Technology, 2014). It is evident that the healthcare sector continues to face significant challenges that require a design and systems approach (Cameron et al., 2019; Reid et al., 2005; Tallack et al., 2020). Over the last two decades, however, there has been a rapid growth in the application of systems-informed approaches to healthcare design and improvement as seen in both the academic and grey literature (Bashford et al., 2018; Hafner and Shiffman, 2013; Komashie et al., 2021; Patou et al., 2020; Ravitz et al., 2018). With such increased application of a systems approach in healthcare, healthcare practitioners and policymakers have become interested in understanding the evidence-base for the approach but very few systematic syntheses of such evidence exist.

In addition to the evidence gap, there is also the challenge of engagement. In a review that looked at the top ten challenges to healthcare quality improvement in the UK, the first two were convincing people that there is a problem and convincing people that the solution proposed is the right one (Dixon-Woods et al., 2012). This suggests that healthcare practitioners are generally sceptical and share divergent views about changes that are aimed at improving the quality of care. Furthermore, there are instances when approaches that have proved successful in industry have been applied to healthcare and not yielded the expected benefits (Nicolay et al., 2012). However, with the current growing interest in a systems approach, there is a lot to be gained if design and systems professionals will engage in this conversation with healthcare practitioners to find effective ways of evidencing the impact of the design and systems approach.

In response to the lack of an evidence-base for systems approaches applied in healthcare, we previously conducted a systematic review and meta-analysis of systems approaches in healthcare based on existing academic literature. While that full systematic review sought to comprehensively map studies adopting systems approaches for health service design, delivery and improvement and quantitatively assess their impact, in this paper we offer our first version of a narrative review to describe the emergence, the nature and the challenges to these systems approaches in healthcare. Specifically, we seek to:

1. Describe the emergence of a systems approach in academic and grey literature within healthcare

2. Examine specific examples against a working definition of a systems approach (involving perspectives on Systems, Design and Risk)

3. Discuss the challenge of evidencing effectiveness of systems approaches

We specifically sought examples of systems approaches in the delivery of care and service improvement. The remainder of this paper is structured as follows: background to define the scope of what we mean by healthcare and systems approach, methodology to summarise our approach in this review. The key findings are presented in the results section and we provide an indebt assessment of the findings in the context of current literature in the discussion section before drawing a few conclusions.

\section{BACKGROUND}

\subsection{Scope: what do we mean by healthcare?}

Engineering design and systems have a lot to say about healthcare (Clarkson, 2018). An obvious area for this is medical devices and equipment where engineers have been involved for as long as the practice of medicine itself. When it comes to care delivery and service improvement however, the role of engineering is not always that obvious. Over the past two decades, various initiatives have been necessitated that are changing our understanding of what engineers can do working together with healthcare practitioners (Clarkson et al., 2017; Reid et al., 2005), thereby expanding the use of systems approaches beyond technology design.

All aspects of healthcare delivery involve systems, exemplified by the broad definition of health systems by the World Health Organization (WHO), as "all organizations, people and actions whose primary intent is to promote, restore or maintain health." (WHO, 2007) Success is defined by the 
ability of the whole system to deliver value to the end user. It is not enough for some parts of the system to be excellent if the whole system is unable to consistently meet the users' needs. This means that a focus on any part at all must be in the context of the whole system and the implications of a change in any part must be understood in terms of how it affects the whole system performance. From an engineering perspective, the first step in realising systems that work, is a deep appreciation of the problem (and stakeholders), followed by an understanding of the system and the ability to describe its structure, function and behaviour, and its underlying need, using standard diagramming techniques (Crawley et al., 2015).

Engineers approach systems with the view that 'systems that work do not just happen - they have be planned, designed and built' (Elliott and Deasley, 2007). And, this is true about product systems, service systems and healthcare delivery systems. By a systems approach, what the authors have in mind is an engineering systems approach which is briefly defined as follows.

\subsection{Definition: A working definition of a systems approach}

A systems approach is difficult to define. In this paper we use the following as a working definition of a systems approach, which has been informed by Clarkson et al.(Clarkson et al., 2017):

A systems approach to healthcare improvement is a way of addressing health delivery challenges that recognises the multiplicity of elements interacting to impact an outcome of interest and implements processes or tools in a holistic way.

This view of a systems approach integrates perspectives on people, systems, design and risk in a way that is applicable to healthcare systems across all scales from local service systems through to organisational, cross-organisational and national policy levels.

\section{METHODOLOGY}

We searched the following databases with no limits on date of publication: Medline, Embase and HMIC (via OVID), Health Business Elite, PsycINFO and CINAHL (via EBSCO) and Web of Science. The choice of these sources was based on discussions with an expert librarian on the topic. The search was last conducted on the 7th of December 2020. We also searched the grey literature from databases held by NHS Evidence covering the same period. NHS Evidence is a national resource in England that holds many records as a source of evidence for health and social care. The search criteria are shown in Box 1. The search was conducted in four steps. In step 1, we searched using key words on the topic of systems. We then used context-related key words in step 2. Step 3 focused the search on the healthcare domain. Step 4 finally used a Boolean AND to amalgamate the results from steps 1 to 3 above. There were no limits on participant types, outcome types or any healthcare domain. All studies that were not in the English language were excluded and there was no limit on study date or health setting.

Box 1. Key words and search methodology

The search was conducted for:

1. System or systems, with all forms of the word approach or engineering or science or methodology or thinking or dynamic or model or complexity or ergonomics or analysis or socio-technical or sociotechnical or theory or system-based or complexity science, Systems Analysis, or systems theory in the titles.

2. Design or deliver or organisation or organization or management or intervention or improvement or implementation or evaluation or quality or assessment or program evaluation or quality control or quality improvement or organizations or "organization and administration" or practice management

3. Healthcare or "health care" or Medicine or "Health service" or care or nursing also in the title

4. 1 AND 2 AND 3. 
For this initial narrative overview of the literature, the lead author conducted the preliminary analysis: (1) tracking of the dates of publications from the full set of academic and grey literature identified from the systematic review ( $\mathrm{n}=10,856$ and 1,119 records respectively), (2) qualitative analysis of how systems approaches were applied across the included studies from the published systematic review $(\mathrm{n}=35)$, and (3) overview on the emerging themes and key findings from existing systematic reviews of systems approaches in health, specifically seeking evidence of effectiveness of systems approaches.

\section{RESULTS}

The results of this preliminary work have been summarised in three parts: the emergence of systems approaches in healthcare, the absence of design and risk thinking in the identified studies, and the challenge of evidencing effectiveness.

\subsection{The emergence of systems approaches in healthcare}

Understanding the emergence of systems approaches in healthcare is important for appreciating the wider context and some of the factors that have driven the increased interest. We compared two sources of data: academic databases $(n=10,856$ records) and grey literature ( $\mathrm{n}=1,119$ records) from NHS Evidence as described in section 3 above. Figure 1 below is the bar chart of counts of systems related records per year from the academic literature and grey literature in the NHS Evidence database (NICE, 2020). The earliest academic record was in 1965 but we have chosen to start the graph from 1970 as that is the point from which the number of records becomes more noticeable.

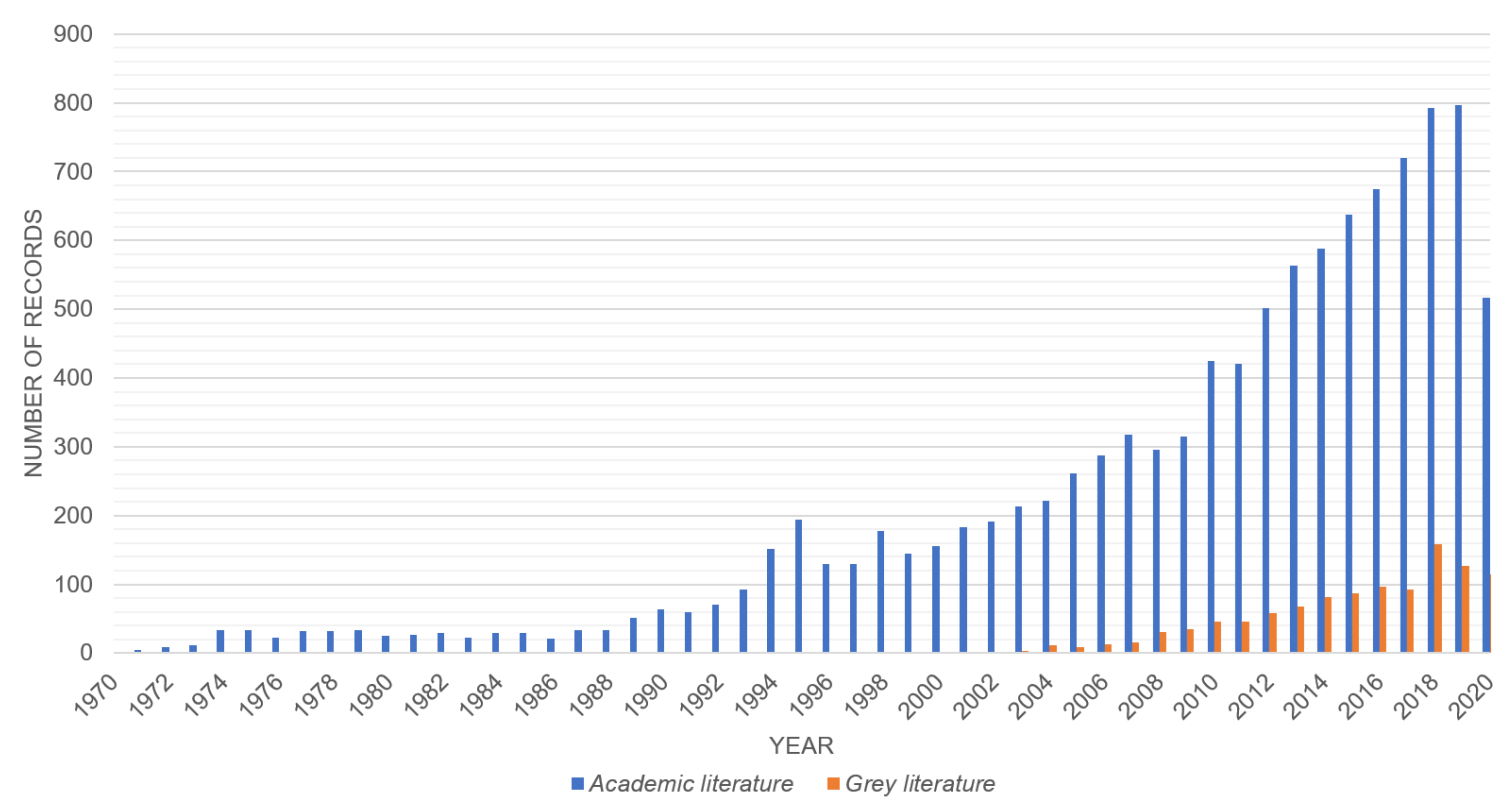

Figure 1. Number of papers per year that mentioned systems in the healthcare literature global academic literature and grey literature within the UK

The emergence of the subject of systems in the grey literature can be clearly seen soon after the start of the century in 2000. The picture from the academic literature, however, is not as sharp though noticeable steady increase in systems related records started earlier, a sharp rise can be seen around the same period.

These trends reflect other important developments for systems approaches and use of such terminology globally. The beginning of the 21 st century marks an important point in the development of systems approaches in healthcare. The WHO's World Health Report 2000 was about improving health systems (WHO, 2000). In addition, two seminal reports in the USA - To err is human (Kohn et al., 2000) and Crossing the Quality Chasm (Institute of Medicine (IOM), 2001) - were also published between 2000 and 2001, which brought healthcare quality and patient safety to centre stage in America. The NHS Plan (Department of Health, 2000) which led to a significant restructuring of healthcare in the UK was also published about the same time.

These developments led to a unique partnership in 2005 between the National Academy of Engineering (NAE) and the Institute of Medicine (IOM) in America that has driven the majority of 
engineering and systems approaches in healthcare to date (Reid et al., 2005). A similar engineeringhealthcare partnership was formed in the UK in 2017, involving the Royal Academy of Engineering, Royal College of Physicians and the Academy of Medical Sciences (AMS) leading to the Engineering Better Care report (Clarkson et al., 2017). This observation is akin to a more extensive historical review of the emergency of global attention to health systems strengthening (Hafner and Shiffman, 2013). Focusing on global health, Hafner and Shiffman suggest that the phenomenon that caused the rapidly increasing attention to health systems strengthening was the concern of global health actors over slow progress on the health MDGs. They expressed doubts about the sustainability of the HSS agenda citing weak evidence base for solutions, amongst other things. Clearly, this trend is likely to continue especially as the challenges facing healthcare are not likely to get any simpler. This is therefore the time for the design and systems community to engage and forge the future together.

\subsection{The absence of design and risk thinking}

Based on the working definition of a systems approach offered earlier in this paper, we sought to understand how well current practice of systems approach aligned with such definition. The assessment was aimed at 35 studies that were included in a recently published systematic review and meta-analysis (Komashie et al., 2021). The studies were assessed based on the extent to which they considered 'Systems' in their approach to improvement, the extent to which they considered 'Systems in the intervention, consideration of 'Design' and consideration of 'Risk'. This assessment was done by a multi-disciplinary team of researchers by discussing the study papers one after another. The team involved engineers with expertise in design, systems engineering and risk, clinicians, and an expert systematic reviewer. The resulting assessment, though subjective, was a collective decision by the team. Brief descriptions of the aspects of a systems approach assessed are provided below:

Consideration of Systems in the approach to improvement: Does study recognise in its approach, the multiplicity of elements contributing to the problem or needed to find a solution?

Consideration of Systems in the intervention: Does the study recognise, in its developed intervention, a multiplicity of elements in the formulation of the intervention or needed to deliver the intervention?

Consideration of Design: Does the study use a design approach in some way (by some exploration of the problem and/or some form of iteration)?

Consideration of Risk: Does the study consider risk in some way?

It is important to note that the assessment of the studies against these criteria was not strict. This means, for example, that a study was judged as 'considering Design' with the slightest indication of seeking to understand the problem and exploring the needs of patients or users. 'Consideration of Risk' was assessed in the same way.

Overall, most of the studies had systems thinking in their approach (91.4\%), and in their interventions (94.3\%). The collective agreement of the multi-disciplinary team was that existing systems approaches to healthcare improvement do not sufficiently consider the subject of design or risk. This observation was supported by the fact that not a significant proportion of the studies considered Design (60\%) and even fewer considered Risk (28.6\%). Again, this presents opportunities for design and systems professionals to help in healthcare improvement. Below we provide a few examples of how Design and Risk concepts were applied, using a selection of studies.

With a problem framed in a whole systems context, Chandrasekar and colleagues (Chandrasekar et al., 2017) aimed to improve mortality for patients with Acute Kidney Injury (AKI) in a hospital in the United Kingdom. Though a consideration of design was limited, the study followed an approach the emphasised an exploration of the problem through the mapping of patient journeys, current processes, and the use of a driver diagram. There was an explicit consideration of risk in the study including guidelines for risk assessment of peri-operative AKI.

Another study aimed at improving medical emergency room performance using a collective systems design methodology (Cochran et al., 2018) demonstrated considerations of design and risk on a problem framed in a systems context. In the study conducted in the USA, design considerations were explicit, including the steps taken to explore the problem through the understanding of user needs and development of functional requirements for the proposed intervention. The consideration of patient and staff safety as part of user needs was satisfactory for the risk consideration.

Researchers in Singapore, working to reduce wrong intraocular lens implants in cataract surgery (Loh et al., 2017) employed the Systems Engineering Initiative for Patient Safety (SEIPS) model which 
encourages the divergent thinking that is characteristic of a design approach. The focus on reducing errors in this study was considered a patient safety issues and therefore addressing risk.

Two further examples of studies conducted in the USA (McGrath et al., 2019; Srinivasan et al., 2017) the considerations of design and risk in the delivery of a systems approach in healthcare. McGrath and colleagues demonstrated how a systems-level design and analysis can be applied in improving clinical monitoring systems. Following elicitation of desired improvements and compilation of feature list, workshops were held with various stakeholders to develop integration, installation workflow and safety specifications and processes for a selected system. Finally, Srinivasan et al. undertook a quality improvement project to increase the rate of NG hydration in eligible children 1 to 23 months old with bronchiolitis by $20 \%$ over 6 months. Like Chandrasekar and colleagues, the design consideration in this study was based on the extent of the exploration of the problem including the use of a driver diagram to map out the various aspects of the issue.

Interestingly, these examples that illustrate design and risk to varying extents, do not represent the norm. As shown above, most studies that set out to use a systems approach to healthcare interventions for improvement do not sufficiently explore the problem nor are considerate of what could go wrong (risk).

\subsection{The challenge of evidencing effectiveness}

Healthcare as a field has become particularly focused on providing evidence for both clinical and improvement interventions especially over the past few decades. As an emerging topic in healthcare improvement, a systems approach will continue to realise its full potential in the field only if the evidence for its effectiveness becomes convincing. One way to being to understand the state of the evidence for the approach is to look at systematic reviews. We found 12 reviews of various kinds that have been conducted on systems approaches to healthcare within the past ten years. Table 1 shows those reviews with their titles, healthcare domain (e.g., Public Health, Global Health etc), type of systems approach (e.g., Engineering Systems Approach, Complex Adaptive Systems etc.) and a summary of conclusions drawn from the review.

Table 1. Reviews of systems related approaches in healthcare in the last 10 years

\begin{tabular}{|c|c|c|c|c|}
\hline Review & Title & $\begin{array}{l}\text { Healthcar } \\
\text { e domain }\end{array}$ & $\begin{array}{l}\text { Type of systems } \\
\text { approach }\end{array}$ & $\begin{array}{l}\text { Summary of } \\
\text { conclusions }\end{array}$ \\
\hline $\begin{array}{l}\text { (Chunghtai } \\
\text { and } \\
\text { Blanchet, } \\
\text { 2017) }\end{array}$ & $\begin{array}{l}\text { Systems thinking in } \\
\text { public health: a } \\
\text { bibliographic } \\
\text { contribution to a meta- } \\
\text { narrative review }\end{array}$ & $\begin{array}{l}\text { Public } \\
\text { Health }\end{array}$ & $\begin{array}{l}\text { Systems } \\
\text { Thinking: CAS, } \\
\text { Complexity } \\
\text { science, } \\
\text { Complexity } \\
\text { theory, non- } \\
\text { linear dynamic }\end{array}$ & $\begin{array}{l}\text { Increasing popularity in } \\
\text { Public Health but level of } \\
\text { understanding remains } \\
\text { unclear. }\end{array}$ \\
\hline $\begin{array}{l}\text { (Rusoja et } \\
\text { al., 2018) }\end{array}$ & $\begin{array}{l}\text { Thinking about } \\
\text { complexity in health: A } \\
\text { systematic review of } \\
\text { the key systems } \\
\text { thinking and } \\
\text { complexity ideas in } \\
\text { health }\end{array}$ & $\begin{array}{l}\text { Health - } \\
\text { Any } \\
\text { setting }\end{array}$ & $\begin{array}{l}\text { Systems } \\
\text { Thinking, } \\
\text { Complexity } \\
\text { Science and } \\
\text { CAS }\end{array}$ & $\begin{array}{l}\text { Found no Systems } \\
\text { Thinking/Complexity } \\
\text { Science "canon". Topic } \\
\text { rapidly increasing but } \\
\text { examples remain largely } \\
\text { theoretical. }\end{array}$ \\
\hline $\begin{array}{l}\text { (Komashie } \\
\text { et al., } \\
2021)\end{array}$ & $\begin{array}{l}\text { A systems approach to } \\
\text { healthcare design, } \\
\text { delivery and } \\
\text { improvement: A } \\
\text { systematic review and } \\
\text { meta-analysis }\end{array}$ & $\begin{array}{l}\text { Health - } \\
\text { Any } \\
\text { setting }\end{array}$ & $\begin{array}{l}\text { Engineering } \\
\text { Systems } \\
\text { Approach }\end{array}$ & $\begin{array}{l}\text { Use of Systems } \\
\text { Approach has statistically } \\
\text { significant impact on } \\
\text { both patient and service } \\
\text { outcomes, but quality of } \\
\text { included studies was low }\end{array}$ \\
\hline $\begin{array}{l}\text { (Wilkinson } \\
\text { et al., } \\
\text { 2018) }\end{array}$ & $\begin{array}{l}\text { The application of } \\
\text { systems thinking } \\
\text { concepts, methods, and } \\
\text { tools to global health } \\
\text { practices: An analysis } \\
\text { of case studies }\end{array}$ & $\begin{array}{l}\text { Global } \\
\text { Health }\end{array}$ & $\begin{array}{l}\text { Systems } \\
\text { Thinking }\end{array}$ & $\begin{array}{l}\text { Potential benefits of } \\
\text { Systems Thinking in } \\
\text { global health but it has } \\
\text { yet to transition from } \\
\text { theory to practice. }\end{array}$ \\
\hline
\end{tabular}




\begin{tabular}{|c|c|c|c|c|}
\hline $\begin{array}{l}\text { (Wutzke et } \\
\text { al., 2016) }\end{array}$ & $\begin{array}{l}\text { Systems approaches for } \\
\text { chronic disease } \\
\text { prevention: sound logic } \\
\text { and empirical evidence, } \\
\text { but is this view shared } \\
\text { outside of academia? }\end{array}$ & $\begin{array}{l}\text { Chronic } \\
\text { Disease } \\
\text { Prevention }\end{array}$ & $\begin{array}{l}\text { Systems } \\
\text { Thinking- } \\
\text { Systems Science }\end{array}$ & $\begin{array}{l}\text { Promising and important } \\
\text { role to play in Chronic } \\
\text { Disease Prevention but } \\
\text { requires further } \\
\text { development and } \\
\text { refinement, and } \\
\text { promotion of case studies } \\
\text { of effectiveness. }\end{array}$ \\
\hline $\begin{array}{l}\text { (Thompson } \\
\text { et al., } \\
2016)\end{array}$ & $\begin{array}{l}\text { Scoping review of } \\
\text { complexity theory in } \\
\text { health services research }\end{array}$ & $\begin{array}{l}\text { Health } \\
\text { Services } \\
\text { Research }\end{array}$ & $\begin{array}{l}\text { Complexity } \\
\text { Theory }\end{array}$ & $\begin{array}{l}\text { Shows promise in Health } \\
\text { Services Research but } \\
\text { conceptual confusion and } \\
\text { inconsistent applications } \\
\text { exist. }\end{array}$ \\
\hline $\begin{array}{l}\text { (Werner } \\
\text { and } \\
\text { Holden, } \\
\text { 2015) }\end{array}$ & $\begin{array}{l}\text { Interruptions in the } \\
\text { wild: Development of a } \\
\text { sociotechnical systems } \\
\text { model of interruptions } \\
\text { in the emergency } \\
\text { department through a } \\
\text { systematic review }\end{array}$ & $\begin{array}{l}\text { Emergency } \\
\text { Departmen } \\
t\end{array}$ & $\begin{array}{l}\text { Socio-technical } \\
\text { systems }\end{array}$ & $\begin{array}{l}\text { Socio-Technical Systems } \\
\text { model of interruptions in } \\
\text { complex settings is } \\
\text { proposed. }\end{array}$ \\
\hline $\begin{array}{l}\text { (Penney et } \\
\text { al., 2018) }\end{array}$ & $\begin{array}{l}\text { Interventions to reduce } \\
\text { readmissions: can } \\
\text { complex adaptive } \\
\text { system theory explain } \\
\text { the heterogeneity in } \\
\text { effectiveness? A } \\
\text { systematic review }\end{array}$ & $\begin{array}{l}\text { Care } \\
\text { Transitions }\end{array}$ & $\begin{array}{l}\text { Complex } \\
\text { Adaptive } \\
\text { Systems }\end{array}$ & $\begin{array}{l}\text { Interventions involving } \\
\text { learning and self- } \\
\text { organisation associated } \\
\text { with improved hospital } \\
\text { readmissions. }\end{array}$ \\
\hline $\begin{array}{l}\text { (Carey et } \\
\text { al., 2015) }\end{array}$ & $\begin{array}{l}\text { Systems science and } \\
\text { systems thinking for } \\
\text { public health: a } \\
\text { systematic review of } \\
\text { the field }\end{array}$ & $\begin{array}{l}\text { Public } \\
\text { Health }\end{array}$ & $\begin{array}{l}\text { Systems Science } \\
\text { - Systems } \\
\text { Methodologies }\end{array}$ & $\begin{array}{l}\text { A great deal of interest in } \\
\text { systems concepts in } \\
\text { Public Health. Soft } \\
\text { Systems Methodology } \\
\text { (SSM) likely to be most } \\
\text { useful. }\end{array}$ \\
\hline $\begin{array}{l}\text { (Xie and } \\
\text { Carayon, } \\
2015)\end{array}$ & $\begin{array}{l}\text { A systematic review of } \\
\text { Human Factors and } \\
\text { Ergonomics (HFE)- } \\
\text { based healthcare system } \\
\text { redesign for quality of } \\
\text { care and patient safety }\end{array}$ & $\begin{array}{l}\text { Patient } \\
\text { Safety }\end{array}$ & $\begin{array}{l}\text { Systems } \\
\text { Engineering } \\
\text { Initiative for } \\
\text { Patient Safety } \\
\text { (SEIPS) model }\end{array}$ & $\begin{array}{l}\text { Found some empirical } \\
\text { evidence that SEIPS } \\
\text { model improves patient } \\
\text { safety and reduces errors } \\
\text { but further research } \\
\text { needed. }\end{array}$ \\
\hline $\begin{array}{l}\text { (Sturmberg } \\
\text { et al., } \\
\text { 2014) }\end{array}$ & $\begin{array}{l}\text { Systems and } \\
\text { complexity thinking in } \\
\text { the general practice } \\
\text { literature: An } \\
\text { integrative, historical } \\
\text { narrative review }\end{array}$ & $\begin{array}{l}\text { General } \\
\text { Practice }\end{array}$ & $\begin{array}{l}\text { Complexity } \\
\text { Science - CAS } \\
\text { theory }\end{array}$ & $\begin{array}{l}\text { General Practice first } \\
\text { embraced systems } \\
\text { theories through } \\
\text { conscious reorganisation } \\
\text { of boundaries before } \\
\text { applying empirical tools. }\end{array}$ \\
\hline $\begin{array}{l}\text { (Jordan, } \\
\text { 2012) }\end{array}$ & $\begin{array}{l}\text { Systems engineering in } \\
\text { health care: Overview } \\
\text { and examples from The } \\
\text { University of Texas } \\
\text { MD Anderson Cancer } \\
\text { Centre }\end{array}$ & Oncology & $\begin{array}{l}\text { Systems } \\
\text { engineering }\end{array}$ & $\begin{array}{l}\text { Efficiency, patient flow, } \\
\text { and patient and staff } \\
\text { satisfaction can be } \\
\text { improved. }\end{array}$ \\
\hline
\end{tabular}

Space limitations will not permit all the possible themes in the table to be explored. The more significant theme is that of evidence of effectiveness as may be seen in the conclusion column. All studies seem to report a great potential for systems approaches to have positive impact on healthcare delivery but then evaluating effectiveness of these approaches presents a challenge. Two of the 
reviews above (Rusoja et al., 2018; Wilkinson et al., 2018) also note the largely theoretical nature of the studies included. There are several challenges to effective evaluation of systems approaches in healthcare including locating studies, appraising studies, synthesising results and lack of design or system specific systematic review processes (Lame, 2019). There is, clearly, considerable interest in assessing the evidence-base for the approach, however, these reviews have not been comprehensive enough and lack focus on patient and service outcomes. Taking a broader approach, a more recent systematic review and meta-analysis that looked at healthcare without time limits has found, across 35 included studies, that a systems approach to healthcare is significantly likely to lead to improvements in both patient and service outcomes (Komashie et al., 2021).

\section{DISCUSSIONS}

This study set out to explore the emergence of systems-based approaches in the healthcare literature. It also assessed several examples included in a recent systematic review against a working definition of a systems approach and, finally, reviewed the challenges to the approach by examining existing reviews published over the past 10 years.

There has been a growing interest in systems approaches to healthcare improvement seen at the start of the century. This appears to coincide with a steady increase in academic studies applying systems approaches in practice. Existing reviews of the approach have often focused on specific healthcare domains, for example patient safety (Waterson, 2009), public health (Carey et al., 2015; Chunghtai and Blanchet, 2017) and global health (Wilkinson et al., 2018). A more comprehensive review of the approach across the entire healthcare literature has been relatively lacking.

Our preliminary in-depth analysis of studies that have implemented a systems approach in practice $(n=35$ from a previous systematic review and meta-analysis) shows two things: first, limited studies demonstrate application of a systems approach to the full extent (elements of Design and Risk were often lacking), and second, while systems approaches are considered beneficial, the evidence-base remains relatively of low quality in the literature. There is a growing call for more robust methods of measuring their benefit and impact. These findings further support conclusions by McGill and colleagues that methodological innovations in the evaluation of systems approaches in healthcare are needed in the increasingly complex health sector (McGill et al., 2021). Despite these limitations, we argue that what is needed is not a quick dismissal of these approaches, especially given the potential demonstrated in the studies identified in the referenced systematic review and the clear policy support for improving how we tackle health system challenges. Rather, we would argue for further attention to finding more innovative measure of effectiveness of the approach in health settings, to identify why such evidence is difficult to obtain, and whether more contextualised and specific evidence frameworks are needed for the breadth of specific systems interventions. This initial literature overview begins to explore these themes in the selected studies, which will lead to a full narrative review of why and how systems interventions work and can be measured in our future work.

\section{CONCLUSIONS}

We conclude that a systems approach will continue to see increasing application in healthcare, encouraged by the emergence of studies demonstrating this. However, we note that current practice in systems approaches to healthcare design and improvement predominantly focuses on the systems perspective but lacks appreciation of design and risk perspectives. There is also a clear need for better evidence to demonstrate the effectiveness of systems approaches across the literature. There is, therefore, a clear research agenda in developing better methodologies for evaluating the systems approach to further establish its value.

\section{ACKNOWLEDGMENTS}

This study was funded by the Healthcare Improvement Studies Institute (THIS Institute), University of Cambridge and the National Institute for Health Research (NIHR) Global Health Research Group on Neurotrauma, University of Cambridge using UK aid from the UK Government to support global health research. THIS Institute is supported by the Health Foundation, an independent charity committed to bringing about better health and healthcare for people in the UK. The views expressed in this publication are those of the authors and not necessarily those of the NIHR or the UK government. 


\section{REFERENCES}

Bashford, T., John Clarkson, P., Menon, D.K. and Hutchinson, P.J.A. (2018), “Commentary Unpicking the Gordian knot: A systems approach to traumatic brain injury care in low-income and middle-income countries", BMJ Global Health, Vol. 3 No. 2, pp. 1-5.

Cameron, G., Alderwick, H., Bowers, A. and Dixon, J. (2019), Shaping Health Futures: Preparing for Tomorrow's Possibilities Today, available at: https://www.health.org.uk/publications/reports/shapinghealth-futures.

Carey, G., Malbon, E., Carey, N., Joyce, A., Crammond, B. and Carey, A. (2015), "Systems science and systems thinking for public health: a systematic review of the field”, BMJ Open, England, Vol. 5 No. 12, p. e009002.

Chandrasekar, T., Sharma, A., Tennent, L., Wong, C., Chamberlain, P. and Abraham, K.A. (2017), “A whole system approach to improving mortality associated with acute kidney injury”, Qjm, Vol. 110 No. 10, pp. 657-666.

Chunghtai, S. and Blanchet, K. (2017), "Systems thinking in public health: a bibliographic contribution to a meta-narrative review", Health Policy and Planning, Vol. 32, pp. 585-594.

Clarkson, P.J. (2018), "What has engineering design to say about healthcare improvement?", Design Science, Vol. 4, pp. 1-35.

Clarkson, P.J., Bogle, D., Dean, J., Tooley, M., Trewsby, J., Vaughan, L., Adams, E., et al. (2017), Engineering Better Care: A Systems Approach to Health and Care Design and Continuous Improvement, London, UK, available at: http://www.raeng.org.uk/news/news-releases/2017/september/healthcare-professionals-andengineers-partner-to.

Cochran, D., Swartz, J., Elahi, B. and Smith, J. (2018), "Using the Collective System Design Methodology to Improve a Medical Center Emergency Room Performance”, Journal of Medical Systems, Vol. 42 No. 12, p. 242.

Crawley, E., Cameron, B. and Selva, D. (2015), System Architecture: Strategy and Product Development for Complex Systems, Global edi., Pearson, Edinburgh.

Department of Health. (2000), The NHS Plan: A Plan for Investment, a Plan for Reform, Vol. Cm 4818-I, available at:https://doi.org/10.1136/bmj.321.7257.315.

Dixon-Woods, M., McNicol, S. and Martin, G. (2012), "Ten challenges in improving quality in healthcare: Lessons from the Health Foundation's programme evaluations and relevant literature”, BMJ Quality and Safety, Vol. 21 No. 10, pp. 876-884.

Elliott, C. and Deasley, P. (2007), "Creating Systems That Work: Principles of Engineering Systems for the 21st Century”, The Royal Academy of Engineering, No. 293074, available at: https://doi.org/1-903496-34-9.

Hafner, T. and Shiffman, J. (2013), "The emergence of global attention to health systems strengthening", Health Policy and Planning, Vol. 28 No. 1, pp. 41-50.

Institute of Medicine (IOM). (2001), Crossing the Quality Chasm. Crossing the Quality Chasm: A New Health System for the 21st Century, National Academies Press, available at:https://doi.org/10.17226/10027.

Jordan, V.S. (2012), "Systems engineering in health care: Overview and examples from The University of Texas MD Anderson Cancer Center", Journal of Clinical Oncology, American Society of Clinical Oncology, Vol. 30 No. 34 SUPPL. 1, available at: http://meeting.ascopubs.org/cgi/content/abstract/30/34_suppl/ 137? sid=014a97b9-9e8d-421b-8ff7-ea1ab05dc98c.

Kohn, L.T., Corrigan, J. and Donaldson, M.S. (2000), To Err Is Human: Building a Safer Health System, National Academy Press, Washington, D.C.

Komashie, A., Ward, J., Bashford, T., Dickerson, T., Kaya, G.K., Liu, Y., Kuhn, I., et al. (2021), "Systems approach to health service design, delivery and improvement: A systematic review and meta-analysis", BMJ Open, available at:https://doi.org/10.1136/bmjopen-2020-037667.

Lame, G. (2019), "Systematic literature reviews: An introduction”, Proceedings of the International Conference on Engineering Design, ICED, Vol. 2019-Augus No. August, pp. 1633-1642.

Loh, H.P., de Korne, D.F., Chee, S.P. and Mathur, R. (2017), "Reducing wrong intraocular lens implants in cataract surgery- 3 years of experience with the SEIPS framework in Singapore", International Journal of Healthcare Quality Assurance, Vol. 30 No. 6, pp. 492-505.

McGill, E., Er, V., Penney, T., Egan, M., White, M., Meier, P., Whitehead, M., et al. (2021), "Evaluation of public health interventions from a complex systems perspective: A research methods review", Social Science and Medicine, Elsevier Ltd, Vol. 272, p. 113697.

McGrath, S.P., Perreard, I.M., Garland, M.D., Converse, K.A. and Mackenzie, T.A. (2019), "Improving Patient Safety and Clinician Workflow in the General Care Setting With Enhanced Surveillance Monitoring", IEEE Journal of Biomedical and Health Informatics, IEEE, Vol. 23 No. 2, pp. 857-866.

NICE. (2020), "NHS Evidence”, available at: https://www.nice.org.uk/about/what-we-do/evidenceservices/evidence-search/evidence-search-content. 
Nicolay, C.R., Purkayastha, S., Greenhalgh, A., Benn, J., Chaturvedi, S., Phillips, N. and Darzi, A. (2012), "Systematic review of the application of quality improvement methodologies from the manufacturing industry to surgical healthcare", British Journal of Surgery, Vol. 99 No. 3, pp. 324-335.

Patou, F., Ciccone, N., Thorpe, J. and Maier, A. (2020), "Designing P4 healthcare interventions for managing cognitive decline and dementia: where are we at?", Journal of Engineering Design, Taylor \& Francis, Vol. 31 No. 7, pp. 379-398.

Penney, L.S., Nahid, M., Leykum, L.K., Lanham, H.J., Noël, P.H., Finley, E.P. and Pugh, J. (2018), "Interventions to reduce readmissions : can complex adaptive system theory explain the heterogeneity in effectiveness? A systematic review", BMC Health Services Research, Vol. 18 No. 894, pp. 1-10.

Pool, E.H. and Bancroft, F.W. (1917), "Systematization of a surgical service", JAMA - Journal of the American Medical Association, Vol. LXIX No. 19.

President's Council of Advisors on Science and Technology. (2014), "Report To the President: Better Health Care and Lower Costs : Accelerating Improvement Through System Engineering”, No. May, p. 66.

Ravitz, A., Grant, M.C. and Grant, C. (2018), "The future of healthcare through a systems approach", 13th System of Systems Engineering Conference, SoSE 2018, IEEE, pp. 527-534.

Reid, P.P., Compton, W.D., Grossman, J.H. and Fanjiang, G. (2005), Building a Better Delivery System: A New Engineering/Health Care Partnership, The National Academy Press, Washington D.C., available at:https://doi.org/10.17226/11378.

Rusoja, E., Haynie, D., Sievers, J., Mustafee, N., Nelson, F., Reynolds, M., Sarriot, E., et al. (2018), “Thinking about complexity in health : A systematic review of the key systems thinking and complexity ideas in health", Journal of Evaluation in Clinical Practice, Vol. 24, pp. 600-606.

Srinivasan, M., Pruitt, C., Casey, E., Dhaliwal, K., De Santo, C., Markus, R. and Rosen, A. (2017), "Quality improvement initiative to increase the use of nasogastric hydration in infants with bronchiolitis", Hospital Pediatrics, Vol. 7 No. 8, pp. 436-443.

Sturmberg, J.P., Martin, C.M. and Katerndahl, D.A. (2014), "Systems and complexity thinking in the general practice literature: An integrative, historical narrative review", Annals of Family Medicine, Vol. 12 No. 1, pp. 66-74.

Tallack, C., Charlesworth, A., Kelly, E., Mcconkey, R. and Rocks, S. (2020), The Bigger Picture: Learning from Two Decades of Changing NHS Care in England.

Thompson, D.S., Fazio, X., Kustra, E., Patrick, L. and Stanley, D. (2016), "Scoping review of complexity theory in health services research", BMC Health Services Research, BMC Health Services Research, Vol. 16 No. 1, available at:https://doi.org/10.1186/s12913-016-1343-4.

Waterson, P. (2009), “A critical review of the systems approach within patient safety research", Ergonomics, Vol. 52 No. 10, pp. 1185-1195.

Werner, N.E. and Holden, R.J. (2015), "Interruptions in the wild: Development of a sociotechnical systems model of interruptions in the emergency department through a systematic review", Applied Ergonomics, England, Vol. 51, pp. 244-254.

WHO. (2000), Health Systems: Improving Performance, World Health Report 2000, available at: https://doi.org/10.1146/annurev.ecolsys.35.021103.105711.

WHO. (2007), Everybody's Business: Strengthening Health Systems to Improve Health Outcomes, available at: https://apps.who.int/iris/bitstream/handle/10665/43918/9789241596077_eng.pdf.

Wilkinson, J., Goff, M., Rusoja, E., Hanson, C. and Swanson, R.C. (2018), “The application of systems thinking concepts, methods, and tools to global health practices: An analysis of case studies", Journal of Evaluation in Clinical Practice, Vol. 24 No. 3, pp. 607-618.

Wutzke, S., Morrice, E., Benton, M. and Wilson, A. (2016), "Systems approaches for chronic disease prevention: sound logic and empirical evidence, but is this view shared outside of academia?", Public Health Research \& Practice, Vol. 26 No. 3, pp. 1-6.

Xie, A. and Carayon, P. (2015), “A systematic review of Human Factors and Ergonomics (HFE)- based healthcare system redesign for quality of care and patient safety", Ergonomics, Vol. 58 No. 1, pp. 33-49. 